\title{
LEARNING AMID CRISIS: EFL STUDENTS' PERCEPTION ON ONLINE LEARNING DURING COVID-19 OUTBREAK
}

\author{
Kasyfur Rahman \\ Universitas Islam Negeri Mataram \\ kasyfurrahman@uinmataram.ac.id
}

\begin{abstract}
This paper investigated tertiary EFL students' overall perception of the use of fully online learning during the Covid-19 pandemic. By administering a survey to 125 students of the English Language Education Program in a State Islamic University in West Nusa Tenggara, Indonesia, using 26 items of a questionnaire with a five-point Likert scale, this study unravelled students' responses in terms of three constructs including Perceived Usefulness (PU), Perceived Ease of Use (PEOU) and Perceived Instructor Characteristics (PIC). The findings suggested that in terms of PU, even though the data mostly demonstrated neutral responses for most of the questionnaire items, the students tended to perceive online learning as to provide flexible time for their learning and foster their autonomy/independence and confidence. However, the students tended to perceive online learning as less facilitating for their understanding of subjects. In terms of PEOU, the responses reflected the students' readiness to employ online learning as the data suggested that they possessed both the technology and the knowledge to use it. However, they tended to encounter problems when operating the technology, especially concerning the internet connection. On the other hand, these students perceived instructor characteristics as mostly positive. Therefore, online learning seemed to have not been designed to engage all students, yet seemed to be an inevitable option during the outbreak as the report from the interviews demonstrated that F2F classes were still preferred over online learning. Finally, these findings imply the need for redesigning online learning to better engage students in virtual classes.
\end{abstract}

Keywords: Online learning, perception, EFL, technology acceptance model

\section{A. INTRODUCTION}

he advent of information technology has made it possible for language learners to communicate synchronously or asynchronously via the internet for virtual classes and has made burgeoning offers of online learning across various platforms. Online learning has also characterized the new generation learning as "in-your-pocket" and "on-thefly"(Hutchison et al., 2008). More and more higher education institutions worldwide have been adopting online learning to cross the boundaries of brick and mortar classrooms, and Indonesian higher education is no exception. Online learning has increasingly made more accessible learning opportunities for adult and higher education (Tan et al., 2010). A considerable amount of research has also advocated the positive outcomes of online learning (Bhagat et al., 2016). However, it should be carefully noted that it is not the instructional technology that influences students' learning quality, but the instructional strategy (Ally, 2008). The types of technology used to deliver teaching are simply vehicles; the contents and how they are delivered are much more important. 
The outbreak of novel coronavirus disease (Covid-19) started in Wuhan, China, has brought about a sudden shift of learning mode worldwide into full online learning to prevent human-to-human transmission. As stated by political and institutional policies, online learning supports both physical and social distancing campaigns. At the same time, a variety of learning platforms such as Google Classroom, Schoology, Edmodo, Zoom Cloud Meeting and the use of social media Such as WhatsApp, Telegram, and the like have been commenced by the educational institution at various levels to compensate for the suspended face-to-face (F2F) classroom interaction. The appeal to online learning deployment existed before the outbreak in the form of distance online learning, Massive Open Online Course (MOOC), and blended learning, a combination of traditional and online learning. All of which bring potentials to the future of learning. Studies on blended learning, for instance, demonstrated that such type of learning contributed to learning in terms of significant language skill development, improved learning environment, and fostered learning motivation (Albiladi \& Alshareef, 2019). However, the use of technology-mediated instruction will not be successful when the students do not perceive it as meaningful and helpful. Furthermore, in the case of the Covid-19 outbreak, most university students learn at home, thus meet challenges that are likely dreadful and provide tensions as these students go back to their hometown, and often, their home is quite remote from the business and political center. The sudden shift toward unlimited online classes primarily in the Indonesian context has several trade-offs, including limited access to the internet and hitches during online communication.

Numerous research studies on students' perceptions of online learning have been conducted. However, most of which took a limited number of research subjects thus needed a study with larger samples. Many studies also adapted the Technology Acceptance Model as their theoretical framework. This model centers upon how the users of technology perceive the usefulness and the ease of using the technology that will affect their attitudes toward it. Nonetheless, when linked to teaching and learning online, teaching is a matter of technology and the people getting involved, especially the teachers. Since these research studies have mostly not linked technology and the instructor, the writer argues that students' perceptions of online learning should also be linked to the instructor characteristics. The delivery of online learning by the instructor also plays a central role in the perceptions of the students. In other words, such a model focuses on technology, while current research focuses on technologymediated teaching and learning. Besides, the inquiry on students' perceptions of online learning in the context of crisis or pandemic has been of little attention. Therefore, in this study, the writer aims to examine how EFL students at the tertiary level of education perceive 180 
online learning in the Covid-19 pandemic context with larger samples by addressing the following question.

What are EFL students' perceptions of online learning amidst Covid-19 pandemic in terms of its usefulness, ease of use, and instructor characteristics?

\section{B. REVIEW OF LITERATURE}

In the revolution industry 4.0 era and $21^{\text {st }}$-century education, online learning, which uses the internet, has been a new trend. The use of the internet offers a good learning experience that bypasses temporal and spatial constraints. In the context of language learning, the internet provides learners with access to authentic documents and resources beneficial for their language acquisition (Zamari et al., 2012). Online learning will provide enhanced critical function of educational interaction through multiple styles and formats (Anderson, 2008). However, as a relatively new form of learning, there is a need for ground for thinking that underpins the application of online learning or e-learning. There is no specific theory on online learning, per se that can serve as a foundation. However, different theories (behaviourism, cognitive psychology, and constructivism) on learning may contribute to the practice of online learning. As illustrated by Ally (2008), teaching about facts (what) can be accommodated by behaviourist strategies, teaching principles and processes (how) can be attributed to cognitive strategies, and constructivist strategies may be used to teach real-life application and contextual learning. Besides, instead of a well-established theory, current online learning necessitates a learning model that can identify its key variables or constructs, which later can be used to build a theory of learning. By and large, online learning can be categorized based on the communication type (asynchronous and synchronous) and the person involved (collaborative and independent). Asynchronous communication is depicted by a one-way and non-interactive real-time communication in which the instructors provide reading material, playable lecture videos, assigned tasks, and assessment in a manageable time frame. Simultaneously, the synchronous type requires a dynamic real-time communication between instructors and students or between the students and their peers through a live chat, streamed video, or video conferencing. Apart from these, as seen in Figure 1, meaningful online interaction in online learning can be multidimensional, which entails student-tostudent, teacher-to-student, student-to-content, content-to-content, and teacher-to-content interaction. To achieve an adequate level of deep and meaningful learning, one of three forms of interaction (student-to-student, teacher-to-student, student-to-content) should be at a very high level (Anderson, 2008). 


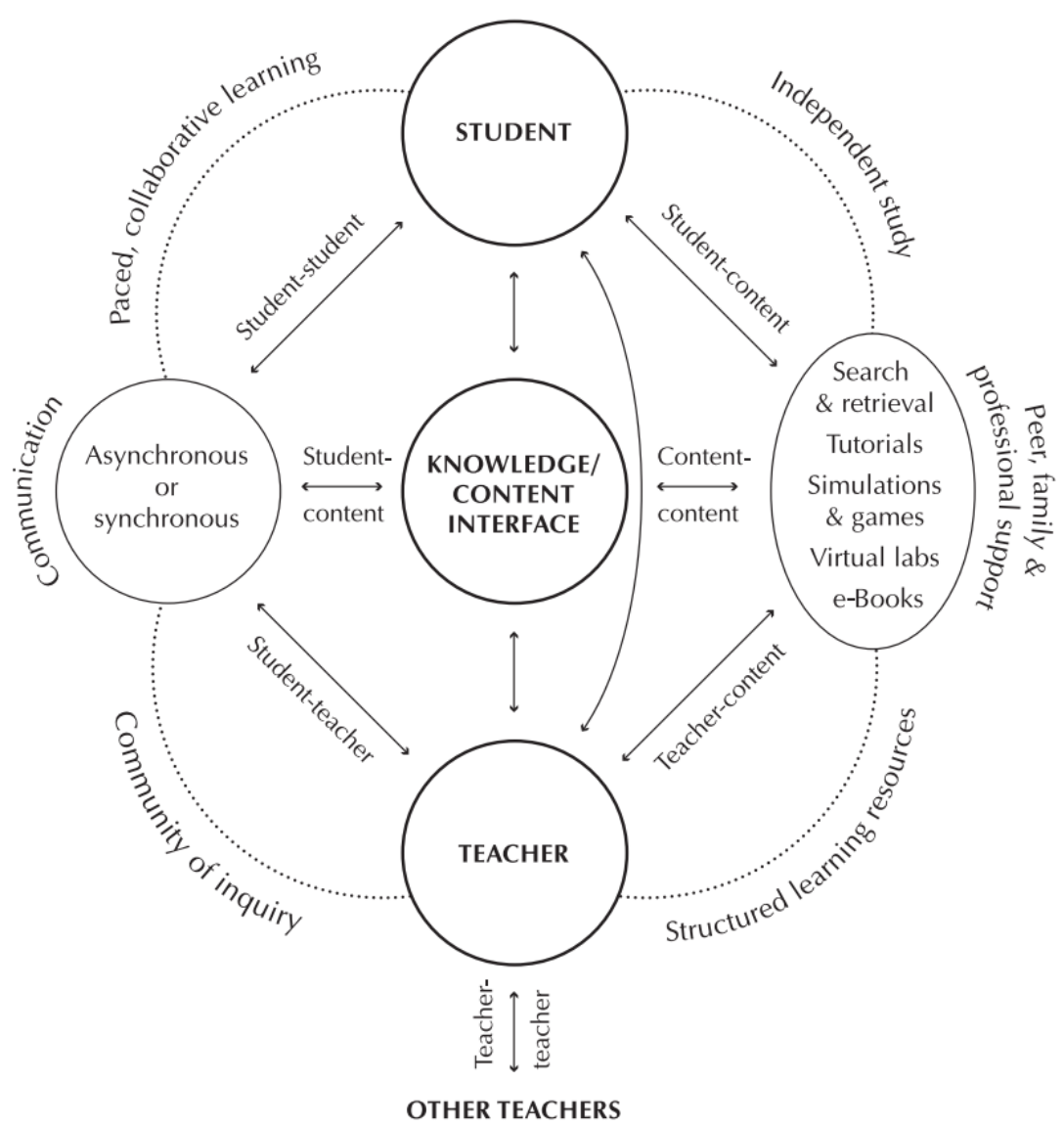

Figure 1 Model of Online Learning (Anderson, 2008)

The success of online learning is multifaceted, and one of the most critical elements is students' perception. When online learning is perceived as beneficial for their learning, students will likely be motivated to perform well (Smart \& Cappel, 2006). Studies on students' perceptions of online learning or e-learning have been extensively carried out across different contexts and educational levels. Findings from Birch and Volkov (2007) revealed that ESL undergraduate students found online discussion beneficial for their social and cognitive learning outcomes, fostered graduate skills, and convenient communication forums. However, some obstacles were found, such as internet connection and time needed to download items. However, this study was limited to the online discussion as part of the online learning assessment in a marketing course and did not address the holistic nature of online learning. Thus, it needs replications and expansions to validate its findings. Another considerable study that attempted to fill this gap was Tan, Nabb, Aagard \& Kim (2010), who addressed how international ESL graduates perceived online learning in terms of broader aspects of learning, namely second language acquisition and cultural diversity. Findings revealed that the students overall perceived online learning as beneficial for vocabulary building and reading and writing improvement, yet perceived it insignificant in promoting 
listening and speaking skills and hindering when it comes to the use of native English vernacular phrases and acronyms. They also reported that in terms of cultural differences, the students came across cultural challenges such as time management, limited experience with technology as well as the nature and content of online discussions.

Nevertheless, their study's main limitation was the small number of samples that counted seven, thus needed larger samples for more reliable findings. A similar inquiry by Zamari, Adnan, Idris \& Yusof (2012) reported a small-scale study on students' perception towards online learning materials that most of the respondents were internally motivated to employ online materials despite a hindrance due to network problems. This study was also limited to a small number of research subjects and a narrow focus on online teaching material; hence it did not highlight how the students perceived online learning. Another recent research study was by Mistar \& Embi (2016) measuring higher education students' perception of Whatsapp as an online learning platform. Findings suggested that at all constructs of measurement, the students reported a high level of attitude, usefulness, and behavioural intention, indicating that Whatsapp is of significant help in improving their learning experience and language proficiency. This study also faced the same issues on a limited number of respondents and only focused on one online learning platform. Research from Daniel, Schumacher, Stelter, and Riley (2016) also reported that graduate students of distance online learning perceived their learning as rigorous as F2F class due to its effectiveness in delivery format. Their respondents reported their online learning featured the instructor's availability, well-timed and positive feedback, and supple course organization. Besides, their study was quite divergent from the previous ones as the online learning under their investigation was well established online distance learning and was the sole learning model used for learning.

On the other hand, previous studies made use of online learning as a complementary scheme of learning. Despite its differences from previous studies, this study faced a similar issue in a small number of research subjects $(\mathrm{N}=47)$. The last study was by Ahamat \& Marsoum (2018), who reported that in Wikispaces' use, ESL students found it enjoyable and fostering language learning experience. In this regard, Wikispaces was used in writing class. Nonetheless, it was only conducted in one class qualitatively. Hence the results could not be generalized.

To sum up, most of these research studies depicted non-generalizable findings due to limited research samples or respondents and qualitative nature. These studies also did not address the students' perceptions regarding an instructor's role and characteristics in online 
learning and did not address how online learning was perceived amid crisis. Therefore, this research aimed to fill the gaps these research studies left.

\section{METHOD}

\section{Respondents}

In this study, 125 EFL students at a State Islamic University in West Nusa Tenggara, Indonesia, 42 males, and 83 females took part as respondents to a designed questionnaire. Most of these students once previously experienced online learning through a blended learning model implemented by several lecturers as parts of the course requirement. These students were in either the second or third year of their study, thus to some extent, they were quite familiar with technology-mediated instruction. When their learning was switched to fully online learning, they had already taken approximately one month of either F2F or blended learning activities. Their even semester started on the $10^{\text {th }}$ of February, and the suspension on the F2F meeting began on the $16^{\text {th }}$ of March 2020.

\section{Instruments}

To garner the intended data, a questionnaire of 26 question items was distributed to the participants. The questionnaire was mostly developed based on Technology Acceptance Model (TAM) (Venkatesh \& Davis, 2000) to measure students' perception of two primary constructs, including Perceived Usefulness (PU) and Perceived Ease of Use (PEOU). An additional construct (Perceived Instructor Characteristics) PIC, which was adapted from Bhagat et al. (2016) POSTOL (Perception of Students towards Online Learning), was also included in the questionnaire since the role of the instructor was considered of paramount importance in the online learning process. Several questionnaire items were modified to suit the need of the research. The questionnaire itself employed a five-option Likert scale that entails 1 (Strongly Disagree), 2 (Disagree), 3 (Neutral), 4 (Agree), and 5 (Strongly Agree). To supplement the analysis on quantitative data, a small-scale interview was also addressed to several respondents.

\section{Procedures}

Before the questionnaire was spread to the participants, a pilot test was carried out on 40 students to measure its validity and reliability. The validity analysis of this questionnaire is a construct validity examined through Kaiser Meyer Olkin (KMO) test, while its reliability was analyzed through the Cronbach Alpha procedure. Once validated, the questionnaire was spread to 125 students, and descriptive analysis was then carried out to see students' perceptions across the three constructs. When the quantitative data were obtained in the form of a survey, the next procedure is to have interviews with 12 students to deepen the data analysis. 


\section{Data analysis}

This paper employed a mixed-method design in which quantitative data were first garnered through a survey employing a questionnaire and were later confirmed through interviews with several respondents. Quantitative data were displayed descriptively to examine the tendencies of students' perception, while the qualitative ones were analyzed through a ubiquitous Miles and Huberman's procedure of qualitative analysis, namely data reduction, data display, and conclusion drawing.

\section{FINDINGS AND DISCUSSION Overview of Participants' Use of Online learning platforms}

As part of the survey, students' demographics and use of online learning platforms vary across them. As seen in the figure below, most of the students reported using social media (95 out of 126) and the learning management system as the leading platforms (97 out of 126). There seemed to be a complementary role between the two platforms. The faculty allowed the lecturers to choose an online learning mode and was not limited to one platform. A combination of two or more platforms was also possible. The data on the responses also showed the use of multiple platforms. Although relatively small, few students reported the use of video conferencing tools or apps and blogs. These small numbers of users were likely to be caused by the resources required by both video conferencing app and blogs, which needed stable internet, heavy user interface, and significant data resources. In the case of these students, many lived in rural regions where internet connection was sometimes unstable apart from their economic constraints.

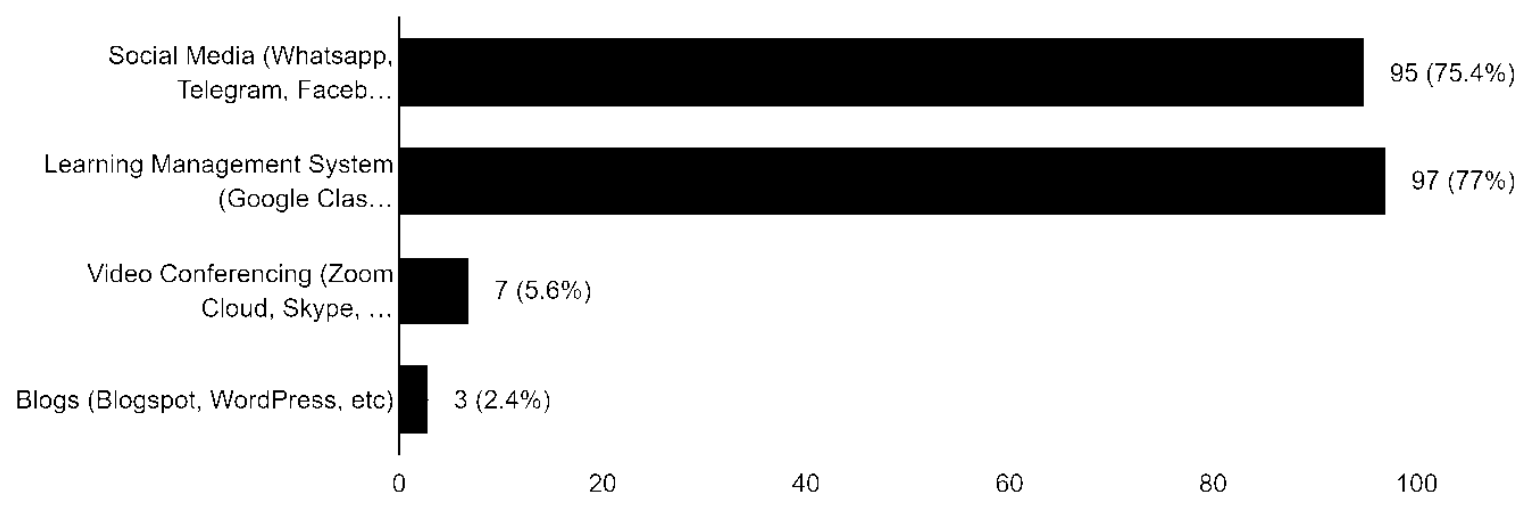

Figure 2 Platforms of Online learning Used by the Students

\section{Validity and Reliability of the Questionnaire}

After pilot-tested to 40 students before distributing the questionnaire to 125 students, the analysis on validity and reliability was carried out to ensure that the questionnaire was 
sufficiently adequate to measure students' perception of online learning. In terms of validity, the analysis through the Kaiser Meyer Olkin test via SPSS 22 yielded the following result, as can be seen in Table 1. KMO is used to describe the ratio between the squared correlation between variables and their partial correlation (Field, 2018). The construct is considered unacceptable when the KMO is below 0.50 , which requires further data collection and more samples. As seen from the table, each construct indicates values higher than 0.50 (PU= 0.770, $\mathrm{PEOU}=0.666, \mathrm{PIC}=0.817)$; therefore, the constructs were acceptable to measure students' perception of online learning. Meanwhile, the outputs of Cronbach alpha demonstrated relatively high reliability $(\mathrm{PU}=0.820, \mathrm{PEOU}=0.792, \mathrm{PIC}=0.912)$. Cronbach alpha signals the overall reliability, categorized as good when the alpha is around 0.80 or 0.70 (Field, 2018). In brief, the three constructs proposed to measure the students' perception were relatively acceptable to use, and the questionnaire designed based on these constructs was both valid and reliable.

Table 1. Questionnaire Validity and Reliability Analysis

\begin{tabular}{lcc}
\hline \multicolumn{1}{c}{ Constructs } & Cronbach alpha $(\alpha)$ & KMO \\
\hline Perceived Usefulness (PU) & 0.820 & 0.770 \\
Perceived Ease of Use & 0.792 & 0.666 \\
(PEOU) & & \\
Perceived Instructor & 0.912 & 0.817 \\
Characteristics (PIC) & & \\
\hline
\end{tabular}

\section{Perceived Usefulness (PU)}

Overall, most of the responses fell within the neutral category, which indicates no tendency over agreement or disagreement among them in terms of online learning usefulness for most of the questionnaire items. Students' perception was also characterized as impartial in which they believed it as useful yet ineffective. This finding thus diverges from previous research (Ahamat \& Masrom, 2018; Binti Mistar \& Embi, 2016; Tan et al., 2010) in which essential findings of their studies suggested online learning as highly beneficial and useful. As demonstrated by the interview data, some were not used to fully online learning despite their previous experiences in using blended learning.

"I think it was useful because our lecturers always tried to make their students active to join the class, but it was not effective. Learning face-to-face is the best 
way because we can directly interact and ask the lecturers about the materials we don't understand. Also, online learning is good for our condition now."

"Since we did the lecture online, there have been positive and negative effects. The positive side was that we were with our family and we could go online while helping our parents, while the negative side was that online lectures left us to learn alone which was ineffective; I was sometimes confused about the task given by my professor. It's just online, like my friend said, we just imagine."

"I think the online learning was useful, especially in the midst of an outbreak like this, so the lesson could continue but not effective, because, during the online learning process, there were a few obstacles that could be encountered, such as a distracted connection, a network. Since the medium was written or video, sometimes it was difficult to understand because it was not directly explained since there were different styles of study that were used to those who did not enjoy reading, it was not effective. So, I chose neutral."

"Actually, online learning was helpful, but it's not effective because students were accustomed to learning face to face, where it made it easy for students to interact directly with the teacher, different from the online class, students sometimes found it difficult or misunderstanding about some of the material."

"I think under the circumstances, online learning was beneficial to get the next courses in this covid19 pandemic because if we didn't do online learning, the lesson would leave behind. So, it's the best way to overcome this problem because we were not allowed to have face-to-face learning in this pandemic situation."

However, in three items (PU3, PU5, and PU7), students' responses indicated slightly more positive perceptions on online learning in terms of given learning time $(M=3,27)$, fostered independence $(M=3,44)$, and improved self-confidence $(M=3,37)$. In terms of time given for learning, most of the students admitted that they had the freedom to manage their time as they could read or access the material posted anytime within the instructors' time frame.

"Because online learning didn't require meetings in each subject, students only waited for material from the lecturer and had sufficient time to study at home. They could access the material anytime and anywhere and also could repeat the material to better understand it. That made students more independent and confident."

"As long as I can see, online learning gave us more time to learn because we could open and repeat the material if we didn't understand yet during the courses."

"How online learning gave more time to learn? Online learning gave more time to learn because students could freely answer the question anytime as long as they did not pass due date." 
Meanwhile, the students' reports also indicated that since it was online, they should have figured out the content material without much-guided learning. Therefore when things got complicated, the flexible time provided enabled the students to search for more information and references from the sea of sources on the internet which were relevant to their course to increase their understanding in case they had not fully grasped the ideas or concepts learned. Furthermore, in the absence of F2F interaction, students' anxiety and inhibition to share ideas or give opinions seemed to be considerably reduced during online learning. As pointed out by Palloff and Pratt (2007), online learning participants are likely to experience a shift of persona, such as the shift from anxiety in the F2F classroom into a more comfortable and active learning environment.

"I think for those who are introverted like me online learning was very fun and enjoyable when we wanted to share opinion because without it was not necessary to be seen by people around, just wrote down our argument. So, it boosted my confidence. And how online learning boosted my independence, it was when we did online learning the explanation was as not as detailed as face to face learning, then when there was something that I was still confused about I could look for another source like watching video on YouTube or googling related courses."

"...because it was online so it would make our confidence increase because most students could deliver their ideas only by writing the answer. Different from face to face learning, the students should have answered directly in front of the lecturer, so sometimes it made students shy to deliver their ideas."

In contrast, the report on PU6 demonstrated the weight on disagreement, which implies a less influential role of online learning on students' conceptual understanding of the given materials and instructions. In terms of understanding, F2F learning seemed to be perceived as more facilitative than virtual classes. This contradicts Daniel et al.'s ((2016) findings on graduate students' perception of professionally designed distance online learning who put online learning on par with F2F classes. The sudden shift towards full online learning due to the Covid-19 outbreak seemed to shock many instructors and students as not all of the instructors had made use of online or blended learning models before the outbreak. In other words, several instructors and students might not have been prepared to anticipate such a sudden shift. To sum up, online learning during the Covid-19 outbreak seemed not to be designed to engage all students. Instead, it was used as an inevitable option for suspended F2F classes.

"In my opinion, online learning could not be effective to enable us to understand the material since in face-to-face class alone, students could only understand a few percent, moreover by online learning. The downside was that 
not all students could be active, and maybe it would affect grades too. I didn't like online learning, but according to the condition and situation, I have to accept it.

"While learning using online media, sometimes a lot of obstacles occurred such as weak internet signals, information that was notified late in cell phones, and sometimes failure to understand material delivered by lecturers. Compared to face-to-face class, online learning was less effective. The atmosphere at home did not support and my parents demanded a lot of works."

"I think the online class was not really useful but it didn't mean effective because sometimes students couldn't understand the material only by using online but we needed to face to face to make clear and to make us easier to understand about what we learned."

"And the next is about believing or not that online class didn't help students' understanding. For me, the truth that I faced is that it didn't really help us to understand the materials. On the contrary, it made us more confused by the various answers available from ourselves and used different vocabulary or explanations."

The more positive perception was also showed by more students who opted either agree or strongly agree on the option in the part of PU7 and PU8. Although there seemed to a balanced response in terms of facilitated interaction (PU9).

Table 2. Students' Perception of the Usefulness of Online Learning

\begin{tabular}{|l|l|l|l|l|l|l|}
\hline \multicolumn{1}{|c|}{ Items } & SD & D & N & A & SA & Mean \\
\hline $\begin{array}{l}\text { (PU1) Overall, I find online learning useful } \\
\text { during the outbreak }\end{array}$ & $6 \%$ & $19 \%$ & $41 \%$ & $19 \%$ & $12 \%$ & 3,13 \\
\hline $\begin{array}{l}\text { (PU2) Online learning provides me with a } \\
\text { wide range of course materials and } \\
\text { references }\end{array}$ & $7 \%$ & $15 \%$ & $46 \%$ & $22 \%$ & $7 \%$ & 3,07 \\
\hline $\begin{array}{l}\text { (PU3) Online learning gives me more time } \\
\text { to learn }\end{array}$ & $6 \%$ & $17 \%$ & $34 \%$ & $26 \%$ & $14 \%$ & 3,27 \\
\hline $\begin{array}{l}\text { (PU4) Online learning improves my } \\
\text { motivation to learn during the outbreak }\end{array}$ & $7 \%$ & $23 \%$ & $34 \%$ & $26 \%$ & $7 \%$ & 3,03 \\
\hline $\begin{array}{l}\text { (PU5) Online learning helps me to be an } \\
\text { independent learner }\end{array}$ & $5 \%$ & $15 \%$ & $30 \%$ & $29 \%$ & $18 \%$ & 3,44 \\
\hline $\begin{array}{l}\text { (PU6) Online learning improves my } \\
\text { understanding on the subjects }\end{array}$ & $16 \%$ & $29 \%$ & $36 \%$ & $14 \%$ & $4 \%$ & 2,61 \\
\hline $\begin{array}{l}\text { (PU7) Online learning improves my } \\
\text { confidence in expressing ideas and opinions }\end{array}$ & $5 \%$ & $11 \%$ & $40 \%$ & $28 \%$ & $14 \%$ & 3,37 \\
\hline $\begin{array}{l}\text { (PU8) Online learning helps improve my } \\
\text { ICT literacy }\end{array}$ & $4 \%$ & $21 \%$ & $45 \%$ & $22 \%$ & $8 \%$ & 3,06 \\
\hline $\begin{array}{l}\text { (PU9) Online learning facilitates interaction } \\
\text { with my classmates and the instructor }\end{array}$ & $8 \%$ & $25 \%$ & $36 \%$ & $20 \%$ & $10 \%$ & 3,00 \\
\hline
\end{tabular}

Perceived Ease of Use (PEOU) 
As reported by the students, most of them were technologically-equipped with very few reporting disagreements about the availability of the equipment (PEOU1, 3\% Strongly disagree, 16\% Disagree) and their knowledge/skills on how to use them (PEOU3, 1\% Strongly disagree, 10\% Disagree). Online learning also allowed most students to organize their learning more flexibly; the percentage of the students who agreed and strongly agreed (24\% and 14\%) that they had time (PEOU2) to join online learning was higher than those who disagree. Time and space constraints are not problems for learners, especially in asynchronous online learning (Ally, 2008). However, there was a discrepancy in the understandability of both the instructors' instructions and materials. In this sense, the continuum tended to lead to disagreement signaling the challenges these students encountered during online learning. Students' responses on PEOU 3 \& PEOU4 also put F2F learning as more rigorous than online learning, reflecting less prepared online learning design. This later confirms that it is not the delivery medium that matters most, but the course design. Ally (2008) emphasizes that online learning developer should be aware of different learning approaches, leading them to design online instructional strategies that are motivating, aiding deep processing, catering to individual differences, promoting meaningful and contextual learning, encouraging interaction, and both facilitating feedback and providing support. Apart from these, the most significant challenges the students reported were mostly on internet access. Although Anderson (2008) points out the increase of access available in developed countries mostly exemplified by countless internet cafes, that is not the case. In the Covid-19 outbreak, a social gathering was not allowed, and many public places were under lockdown policies. Therefore, these students should have relied on their cell phones and limited internet access by either purchasing cellular internet package or staying in their boarding houses in urban areas to obtain shared Wi-Fi access since their hometown was out of internet reach.

"Actually, I felt okay when we did these online classes, but my friends and I had some obstacles such as no signals, no internet, broken cell phones, and others. It made us unable to join the class."

"I didn't have enough money to buy an internet package. I lived in a remote area so the cellular signal sometimes disappeared. My friend who used Zoom said that it took around $1 \mathrm{~GB}$ of internet quota for one single meeting. Moreover, for me who lived in a village."

"In the online class, many students were posting their idea at the same time and it made the instructor or lecturer couldn't evaluate students one by one, different from face to face the lecturer would directly know about students who were active in the class." 
"Online learning spent more time typing and reading learning material, and sometimes students also had little interest in reading so students didn't understand what the lecturer was describing. Therefore, I prefer learning face to face. "

“In my village, there wasn't any internet signal, that's why I haven't gone to my hometown. I really wanted to go home, but because of this online learning, I had to decide to stay in my dorm when everyone was in their hometown. It could be said that I was the only one who stayed there, and I used my dorm's Wi-Fi to access the internet. If I used an internet package that costs $50 \mathrm{~K}$, maybe it would last in three days, so I had to restraint myself from going home."

Fortunately, several higher institutions, including the university in which current research was carried out, issued a policy on free internet access for their students during the outbreak. However, though seeming beneficial, this policy still encountered dilemmatic situations as free internet access did not address all cellular operators available, and the strength of cellular signal differed across regions and internet providers. The internet problem's findings replicated Zamari et al. 's (2012) study that showed network problems faced by motivated students.

Table 3. Students' Perception of the Online Learning Ease of Use

\begin{tabular}{|l|c|c|c|c|c|c|}
\hline \multicolumn{1}{|c|}{ Items } & SD & D & N & A & SA & Mean \\
\hline $\begin{array}{l}\text { (PEOU1) I have the technology to use with } \\
\text { online learning }\end{array}$ & $3 \%$ & $16 \%$ & $28 \%$ & $29 \%$ & $22 \%$ & 3,53 \\
\hline $\begin{array}{l}\text { PEOU2) I have time to get involved in } \\
\text { online learning }\end{array}$ & $4 \%$ & $16 \%$ & $42 \%$ & $24 \%$ & $14 \%$ & 3,26 \\
\hline $\begin{array}{l}\text { (PEOU3) I know how to use the } \\
\text { technology for online learning }\end{array}$ & $1 \%$ & $10 \%$ & $32 \%$ & $30 \%$ & $24 \%$ & 3,70 \\
\hline $\begin{array}{l}\text { (PEOU4) The instructions during online } \\
\text { learning are easy to understand }\end{array}$ & $11 \%$ & $28 \%$ & $39 \%$ & $15 \%$ & $5 \%$ & 2,74 \\
\hline $\begin{array}{l}\text { (PEOU5) The materials provided online are } \\
\text { easy to understand }\end{array}$ & $13 \%$ & $32 \%$ & $36 \%$ & $14 \%$ & $3 \%$ & 2,64 \\
\hline $\begin{array}{l}\text { (PEOU6) Online learning makes it easy to } \\
\text { interact with my classmates and the } \\
\text { instructor }\end{array}$ & $16 \%$ & $28 \%$ & $31 \%$ & $17 \%$ & $7 \%$ & 2,73 \\
\hline $\begin{array}{l}\text { (PEOU7) I have no problem with internet } \\
\text { connection }\end{array}$ & $40 \%$ & $34 \%$ & $18 \%$ & $3 \%$ & $5 \%$ & 1,99 \\
\hline $\begin{array}{l}\text { PEOU8) I did not encounter problems } \\
\text { when joining online learning }\end{array}$ & $22 \%$ & $25 \%$ & $42 \%$ & $9 \%$ & $2 \%$ & 2,44 \\
\hline
\end{tabular}

Perceived Instructor Characteristics (PIC) 
Unlike the previous two constructs that received various reports, perceived instructor characteristics received steady responses from the respondents. All of the items indicated positive responses $(M>3,00)$, which might have probably been linked to online learning students' social presence. As pointed out by Tu (2002) and Cobb (2009), social presence reflects the degree to which one is perceived as 'real' in online communication. Here is where the instructor's role shines; the instructor uses interpersonal negotiation to facilitate effective learning. Overall, the respondents perceived their instructors as friendly, motivating, encouraging, and facilitative. This was indicated by the instructors' awareness of the circumstance under which their students were learning. The instructors communicated with their students about what and how to learn. Meanwhile, they did not get things complicated and did not provide overloading tasks. They also provided immediate feedback to queries, although providing feedback based on individual inquiry was meticulous. Additionally, to create a sense of social presence, the instructor should develop interaction skills (Tu, 2002) as an instructor or moderator role is critical in such respect (Cobb, 2009). This is intended to create a positive vibe in the learners' minds, build trust among instructors and students, promote students' comfort during learning, and encourage their participation.

"I guess that the instructors were friendly, supportive, facilitative, encouraging, etc, from the way they greeted us, gave us the same opportunity to answer the question, and gave feedback while we did the online class, therefore it made us feel more comfortable to enrol this online class."

"The lecturer or instructors were friendly in every meeting the lecturer always greeted the students; lecturers always asked the students to answer the question that had a correlation with the material. After the students answered it the lecturer gave appreciation or applause to the students, the lecturer clarified more details about the answer. The lecturer always gave the new material for students to learn, and always encourages students at every end of the meeting."

"In my opinion, our lecturers were very understanding with our condition, they often asked us what we wanted on online class, they didn't decide by themselves what the method in study was, they considered our problems in online learning, they didn't complicate us if we missed the online class. Also, they would answer all the questions from the students about the material that they didn't understand."

Table 4. Students' Perception on the Instructor Characteristics

\begin{tabular}{|l|l|l|l|l|l|c|}
\hline \multicolumn{1}{|c|}{ Items } & SD & D & N & A & SA & Mean \\
\hline $\begin{array}{l}\text { (PIC1) The instructor is friendly and } \\
\text { approachable }\end{array}$ & $2 \%$ & $14 \%$ & $35 \%$ & $26 \%$ & $19 \%$ & 3,49 \\
\hline (PIC2) The instructor motivates me to learn & $3 \%$ & $16 \%$ & $36 \%$ & $26 \%$ & $16 \%$ & 3,39 \\
\hline (PIC3) The instructor encourages me to & $3 \%$ & $14 \%$ & $35 \%$ & $28 \%$ & $17 \%$ & 3,44 \\
\hline
\end{tabular}




\begin{tabular}{|l|l|l|l|l|l|l|}
\hline interact with him/her and my classmates & & & & & & \\
\hline $\begin{array}{l}\text { (PIC4) The instructor gives me sufficient } \\
\text { learning resources }\end{array}$ & $1 \%$ & $14 \%$ & $32 \%$ & $38 \%$ & $13 \%$ & 3,50 \\
\hline $\begin{array}{l}\text { (PIC5) The instructor gives me feasible } \\
\text { amount of task }\end{array}$ & $2 \%$ & $13 \%$ & $49 \%$ & $24 \%$ & $10 \%$ & 3,27 \\
\hline $\begin{array}{l}\text { (PIC6) The instructor gives me enough time } \\
\text { to do a task }\end{array}$ & $2 \%$ & $14 \%$ & $26 \%$ & $32 \%$ & $22 \%$ & 3,60 \\
\hline $\begin{array}{l}\text { (PIC7) The instructor gives plenty of time } \\
\text { for turn taking during discussion }\end{array}$ & $2 \%$ & $10 \%$ & $47 \%$ & $31 \%$ & $6 \%$ & 3,32 \\
\hline $\begin{array}{l}\text { (PIC8) The instructor solves the emerging } \\
\text { problems during online learning efficiently }\end{array}$ & $2 \%$ & $17 \%$ & $40 \%$ & $26 \%$ & $10 \%$ & 3,30 \\
\hline $\begin{array}{l}\text { (PIC9) The instructor gives quick feedback } \\
\text { to questions }\end{array}$ & $3 \%$ & $16 \%$ & $33 \%$ & $30 \%$ & $15 \%$ & 3,40 \\
\hline
\end{tabular}

\section{E. CONCLUSION}

To sum up, this study's findings demonstrated that while the students perceived online learning as useful during the pandemic, they also thought that online learning was ineffective. This polarized perception is probably since they were not accustomed to fully online learning despite their previous engagement in classes that used blended learning. The students' most problematic situations were their poor understanding of the materials delivered online and technical problems in terms of internet connection and operation. Apart from these, the students mostly showed a positive attitude towards instructor characteristics. Therefore, this research's findings prompt a wake-up call for instructors to immediately change the situation to better engage the students by redefining and redesigning their teaching to facilitate more meaningful and positively perceived lessons. This seems imperative as the pandemic at the time this paper was written was still transmitting across the globe and there was no sign of its end.

\section{REFERENCES}

Ahamat, M. I., \& Masrom, U. K. (2018). Students' perception on the use of wikispaces in ESL classroom. Global Business and Management Research, 10(3), 524.

Albiladi, W. S., \& Alshareef, K. K. (2019). Blended learning in English teaching and learning: A review of the current literature. Journal of Language Teaching and Research, 10(2), 232238.

Ally, M. (2008). Foundations of Educational Theory for Online Learning: Theory and Practice of Online Learning. AU Press, Athabasca Üniversitesi.

Anderson, T. (2008). Towards a theory of online learning (pp 44-74). The Theory and Practise of Online Learning. / Athabasca University. 
Rahman, R., Learning Amid Crisis...

Bhagat, K. K., Wu, L. Y., \& Chang, C.-Y. (2016). Development and validation of the perception of students towards online learning (POSTOL). Journal of Educational Technology \& Society, 19(1), 350-359.

Binti Mistar, I., \& Embi, M. A. (2016). Students 'perception on the use of WhatsApp as a learning tool in ESL classroom. Journal of Education and Social Sciences, 4, 96-104.

Birch, D., \& Volkov, M. (2007). Assessment of online reflections: Engaging English second language (ESL) students. Australasian Journal of Educational Technology, 23(3).

Cobb, S. C. (2009). Social presence and online learning: A current view from a research perspective. Journal of Interactive Online Learning, 8(3).

Daniel, M. C., Schumacher, G., Stelter, N., \& Riley, C. (2016). Student perception of online learning in ESL bilingual teacher preparation. Universal Journal of Educational Research, $4(3), 561-569$.

Field, A. P. (2018). Discovering statistics using IBM SPSS statistics. Vol Fifth. California: Sage Publication.

Hutchison, M., Tin, T., \& Cao, Y. (2008). "In-your-pocket” and" on-the-fly:" Meeting the needs of today's new generation of online learners with mobile learning technology. AU Press.

Palloff, R. M., \& Pratt, K. (2007). Building Online Learning Communities: Effective Strategies for the Virtual Classroom. John Wiley \& Sons.

Smart, K. L., \& Cappel, J. J. (2006). Students' perceptions of online learning: A comparative study. Journal of Information Technology Education: Research, 5(1), 201-219.

Tan, F., Nabb, L., Aagard, S., \& Kim, K. (2010). International ESL graduate student perceptions of online learning in the context of second language acquisition and culturally responsive facilitation. Adult Learning, 21(1-2), 9-14.

Tu, C.-H. (2002). The impacts of text-based CMC on online social presence. Journal of Interactive Online Learning, 1(2), 1-24.

Venkatesh, V., \& Davis, F. D. (2000). A theoretical extension of the technology acceptance model: Four longitudinal field studies. Management Science, 46(2), 186-204.

Zamari, Z. M., Adnan, A. H. M., Idris, S. L., \& Yusof, J. (2012). Students' perception of using online language learning materials. Procedia-Social and Behavioral Sciences, 67, 611-620. 